\title{
SOCIOLOGIA DA DECISÃO \\ JURÍDICA: APLICAÇÃO AO CASO \\ DA HOMOAFETIVIDADE ${ }^{\mathrm{i}}$
}

\author{
SOCIOLOGY OF LEGAL DECISION: \\ APLLIED TO HOMOSESSUAL CASE
}

Artur Stamford da Silva ${ }^{\mathrm{ii}}$

Sumário: 1 Contextualização epistemológica da teoria reflexiva da decisão jurídica. 2 Técnicas e métodos hermenêuticos: nem lacuna nem literalidade nem analogia. $3 \mathrm{O}$ quadro cênico: a intercomposição do discurso jurídico. 4 Observações dos discursos constituintes na formação discursiva do direito da sociedade. Referências.

\section{Resumo}

O neoconstitucionalismo viabilizou a ampliação dos limites da literalidade legalista face à inclusão dos princípios constitucionais. Visando contribuir ao debate, exploramos dados da decisão do STF que equiparou juridicamente a união entre pessoas do mesmo sexo (homossexual, homoafetivas) à entidade familiar entre homem e mulher. Os corpora foram constituídos de documentos (legislações, decisões do STJ, os votos dos ministros do STF, notícias de jornais) e vídeos das audiências no STF. Coletados os enunciados dos participantes, aplicamos a "teoria reflexiva da decisão jurídica" para observar as constantes reentradas de sentido-possível no sentido-corrente, o que nos permitiu verificar

Este trabalho foi realizado com apoio do Conselho Nacional de Desenvolvimento Científico e Tecnológico (CNPq) - Brasil.

${ }_{2}^{2}$ Professor associado da Faculdade de Direito do Recife-UFPE. Pesquisador do CNPq Nível 2. 
como foi possível o STF decidir como decidiu, mesmo com os textos legislativos em vigor no Brasil.

Palavras-chave: Decisão jurídica. Entidade familiar. Teoria dos sistemas. Direito da sociedade. Discurso constituinte.

\begin{abstract}
Neoconstitutionalism made viable the widening of the limits of the legalistic literal aspect in the face of the inclusion of constitutional principles. Seeking to contribute to the debate, we explore the data of the decision of the Supreme Federal Tribunal (STF) which juridically equated the union between two people of the same sex (homosexuals) with the family entity between a man and a woman. The corpora were constituted by documents (legislations, decisions by the $\mathrm{Su}-$ preme Justice Tribunal, votes by ministers of the STF, newspaper items) and videos of audiences in the STF.

Having collected the statements by the participants, we applied the "reflexive theory of juridical decision" to observe the constant re-entries of possible-sense in the ongoing-sense, which permitted us to verify how it was possible for the STF to decide the way it did with the legislative texts now in vigor in Brazil.
\end{abstract}

Keywords: Legal decision. Family. Systems theory. Legal system. Self-constituting discourse.

\section{CONTEXTUALIZAÇÃO EPISTEMOLÓGI- CA DA TEORIA REFLEXIVA DA DECISÃO JURÍDICA}

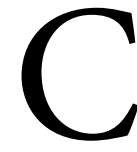
inco de maio de dois mil e onze foi o dia em que o Supremo Tribunal Federal (STF) - após discussão sobre a Ação de Descumprimento de Preceito Fundamental (ADPF 132), impetrada pelo Governo do Estado do Rio de Janeiro, e a Ação Direta de Inconstitucionalidade (ADI 4277), impetrada pelo Procurador Geral da República - decidiu terem as uniões entre pessoas do mesmo sexo (homossexuais) os mesmos direitos e deveres que a união entre homem e mulher, portanto a união homoafetiva integra, para fins jurídicos, a expressão entidade familiar.

Neste caso, ao questionarmos como foi possível o STF ter tomado essa decisão, o que implica questionar como foi possível o STF incluir na expressão "entidade familiar" a união de pessoas do mesmo sexo. Para isso, observamos os discursos dos participantes das audiências, ou seja, do Procurador do Estado do Rio de Janeiro, dos amici curiae, dos Ministros do STF.

O embate se pautou por diversos pontos, exploraremos alguns deles, inclusive, porque não temos por objetivo desenvolver uma hermenêutica constitucional nem estabelecer o que é entidade familiar no direito brasileiro, nem decretar o quanto a decisão tomada foi correta, absurda ou errada. Assim é porque nossas pesquisas partem da ideia que perguntar "o que é" resulta em paradoxo, pois buscar a origem, o princípio, o primeiro motor, a gênese é aplicar causalidade. Epistemologica e gnosiologicamente aplicamos a teoria da circularidade reflexiva ${ }^{1}$, portanto não tautologia nem causalidade ${ }^{2}$. Com isso não cabe questionar o que é uma decisão jurídica, mas sim "como é possível o Judiciário (STJ e STF) tomar as decisões que toma".

Para observar ${ }^{3}$ como é possível o Judiciário decidir como decide, exploramos a decisão do STF de 5 de maio de 2012 e recorremos à teoria sociocognitiva da compreensão como inferên- 
cia $^{4}$ (Marcuschi), à análise de discurso constituinte $^{5}$ (Maingueneau) e à teoria da sociedade como sistema de comunicação ${ }^{6}$ (Luhmann). Este somatório de teorias forma o que denominamos "teoria reflexiva do direito da sociedade".

Esses estatutos epistemológicos nos permitem não cair em conclusões causais tipo: "decisão jurídica é uma questão de poder"; "o direito, texto que é, vago e ambíguo, viabiliza decisão ao sabor da arbitrariedade interpretativa do julgador". Ao substituir a pergunta "o que é" pela, "como é possível”, como indica Luhmann", seguimos um caminho teórico pautado pela reflexividade para explicar e compreender a decisão judicial. As implicações de optar pela pergunta "como é possível" nos conduzem a consequências como, por exemplo, que a decisão jurídica não é uma resultante causal de aplicação da legislação nem de poder, bem como que não cabe falar em "do fato se chega à norma”. Sugerimos que a decisão jurídica é uma operação do sistema jurídico, não uma decisão de um magistrado ${ }^{8}$. Dessa sugestão temos que a produção de sentido do direito da sociedade se dá recursivamente, ou seja, pela reentrada do sentido de uma temática na temática do direito como sistema da sociedade. Sendo sociedade, sistema de sentido, como adiante escrito. Noutras palavras, o direito, sistema de comunicação que é, produz e reproduz o sentido de seus próprios elementos, de suas próprias temáticas, de suas próprias instituições. Observar como o direito opera como sistema que observa requer mudanças gnosiológicas e epistemológicas trazidas pela cibernética, a exemplo da gödelização da racionalidade jurídica ${ }^{9}$. Numa frase, nossas pesquisas indicam que a decisão jurídica não está pré-estabelecida em nenhuma causa que lhe é anterior, tal decisão se estabelece, por contingência, considerando a memória do sentido de direito da sociedade ao mesmo tempo em que ela é o espaço de mudança do direito da sociedade. Como abaixo estará explicitado.

Para desenvolver essa nossa hipótese, tivemos por corpora da pesquisa textos de legislações, documentos da decisão do STF, de 5 de maio de 2011, na Ação Direta de Inconstitucionalidade (ADI) 4277 e na Arguição de Descumprimento de Preceito Fundamental (ADPF) 132, dos vídeos das audiências realizadas no STF, tanto as falas das entidades da sociedade civil (amicus curiae $\left.^{10}\right)$, como os votos enunciados pelos Ministros do STF, ambos totalizando 522 minutos de falas. Coletamos também dados em notícias sobre a repercussão do caso veiculadas em jornais e blogs disponíveis na internet, além de decisões do Superior Tribunal de Justiça (STJ). Os dados foram lançados numa planilha e analisados desde nossa proposta teórica: a teoria reflexiva da sociedade como sistema de comunicação.

Teoria reflexiva é uma perspectiva gnosiológica que se pauta pela circularidade recursiva tal como desenvolvida pela "teoria dos sistemas que observam ${ }^{11}$ ", a qual traz com alternativa à causalidade e à circularidade tautológica a re-

\footnotetext{
${ }^{3}$ Observar é ação de pesquisa realizada pelo observador. A aparência de evidência e simplicidade da afirmação esconde o afastamento de dicotomias, a exemplo: sujeito/objeto; objetividade/subjetividade; neutralidade científica etc. Em seu lugar, reconhecemos que o observador, ao observar, produz uma distinção, portanto realiza, ao mesmo tempo, o estabelecimento da unidade e da diferença do que observa, ou seja, indica, estabelece, destaca, assinala o marcado como observado, paradoxalmente ao que, também determina o diferente, o não observado (LUHMANN, 2007, p. 38-39). Assim, observar não é um ato apenas subjetivo, mas ao mesmo tempo objetivo. Como na análise de discurso, discurso não é um enunciado; na teoria da sociedade como comunicação, comunicar não é só informar, mas também o expressar e o entender (compreender). Com isso, ao observar os dados, o observador não ignora que outros dados, bem como outras leituras são possíveis.

4 "a compreensão é um trabalho social" (MARCUSCHI, 2007a, p. 77; MARCUSCHI, 2008, p. 229).

${ }^{5}$ Constituintes são os discursos que têm a pretensão de "não reconhecer outra autoridade além da sua própria, de não admitir quaisquer outros discursos acima deles. Isso não significa que as diversas outras zonas de produção verbal não exerçam ação sobre eles; bem ao contrário, existe uma interação constante entre discursos constituintes e não constituintes, assim com entre discursos constituintes" (MAINGUENEAU, 2008, p. 37).

${ }^{6}$ Tendo por petição de princípio que a comunicação é a célula da sociedade, Luhmann aplica a teoria da diferenciação de Spencer Browne (teoria da forma de dois lados) distinguindo médium/forma e sistema/meio para afirmar que "Sociedade é sistema de sentido", porquanto sociedade é comunicação organizada em forma de sentido (LUHMANN, 2007, p 28 et seq.).

${ }^{7}$ LUHMANN, 2007, p. 13

${ }^{8}$ STAMFORD DA SILVA, 2009, p. 137; STAMFORD DA SILVA, 2010, p. 125; STAMFORD DA SILVA, 2012a p. 43; STAMFORD DA SILVA, $2012 b$, p. 306.

${ }^{9}$ STAMFORD DA SILVA, 2009, passim.

${ }^{10}$ Trata-se do julgamento da Ação Direita de Inconstitucionalidade n. 4.277, impetrada pelo Procurador Geral da República e a Ação Direta de Preceito Fundamental (ADPF) n. 132, impetrada pelo Estado do Rio de Janeiro. Amici curiae são entidades da sociedade que podem solicitar participação, com direito a voz, em julgamentos do STF, conforme $₫ 2^{\circ}$, art. $7^{\circ}$, da Lei n. 9.868/1999.

${ }^{11}$ FOERSTER, 1987.
} 
flexividade, como é a teoria cibernética da comunicação desenvolvida durante e após os dez encontros da Macy Conference ${ }^{12}$. Ainda que a palavra cibernética tenha estreita relação com governo, direção, controle, na Macy Conference, cibernética é a teoria da comunicação que parte da causalidade circular, não da causalidade linear nem da circularidade tautológica, como se pode constatar com a visão construtivista - no sentido usado por Heinz von Foerster, Gregory Bateson e Humberto Maturana - de ordem cibernética por aplicar ideias como circularidade criativa, a teoria reflexiva, a autopoiesis.

A teoria reflexiva da sociedade como sistema de comunicação porta de Luhmann a concepção de sociedade como sistema de comunicação. É que Luhmann pauta sua visão cognitiva baseado em teorias matemáticas e biológicas, todavia as aplica em sua teoria social transformando-as como bases explicativas da comunicação como célula da sociedade, pois

[...] o sistema sociedade não se caracteriza por uma determinada 'essência' (Wesen) muito menos por uma determinada moral (propagação da felicidade, solidariedade, nivelação de condições de vida, integração por consenso racional etc.), mas sim unicamente pela operação que produz e reproduz a sociedade: isto é a comunicação. Logo, por comunicação se entende um acontecimento que em todo caso sucede de maneira histórico-concreta, um acontecimento que depende de contextos - não se trata, portanto, unicamente de aplicação de regras do falar correto. Acontece que para a efetivação da comunicação é necessário que todos os participantes intervenham com um saber e com um não saber. [...] Como práxis do sentido, a comunicação também se vê obrigada a fazer distinções para assinalar um dos dois lados e provê-lo com enlaces. Com isso se continua a autopoiesis do sistema. ${ }^{13}$

Luhmann, como se pode ler, influenciado pelas ideias de George Spencer Brown, no livro
Laws of Form, publicado em $1979^{14}$, Louis $\mathrm{H}$. Kauffman, ao tratar da autorreferência e da forma recursiva ${ }^{15}$ e por Heinz von Foerster dada a "teoria" dos sistemas que observam ${ }^{16}$. Ao lado desses aportes, ainda na visão de comunicação como célula da sociedade, Luhmann recorre ao construtivismo epistêmico baseado na ideia de autopoiesis trazida pelos biólogos chilenos Maturana e Varela ${ }^{17}$, além da lógica policontextural, como proposto por Gotthard Günther ${ }^{18}$.

Aplicando essa base gnosiológica, Luhmann escreve que a comunicação é uma unidade de três componentes: informação (Information), expressar (Mitteilung) e entendimento (Verstehen) ${ }^{19}$. Esses três elementos estão enlaçados de maneira circular construtivista, pois só por comunicação é que se comunica, daí a comunicação ser autopoiética, ela gera, por si mesma, o entender que ela necessita para operar por comunicação. Quando comunicamos nos referimos a algo, a uma coisa, a um acontecimento. Nas palavras do autor: "a comunicação funciona autorreferencialmente", acontece que "o conceito de sistema remete ao conceito de entorno e, justamente por isso, sistema não se isola nem lógica nem analiticamente" ${ }^{21}$, antes, sendo sistema, sistema de sentido, ele opera no médium sentido realizando a distinção autorreferência e heterorreferência, o que permite a cada informação expressada, o sistema atualizar sua autorreferência ${ }^{22}$.

Essa divisão da unidade da comunicação em três componentes permite a Luhmann afirmar que o limite comunicativo está na maneira como a informação será entendida (aceita ou rejeitada), posto que depende "do desenvolvimento simultâneo de uma extrema dependência social e de um alto grau de individualização: esse desenvolvimento se alcança mediante a construção de uma ordem complexa de comunicação provida

\footnotetext{
${ }^{12}$ WIENER, 1965.

${ }^{13}$ LUHMANN, 2007, p. 47-48.

${ }^{14}$ LUHMANN, 2007, p. 28, 40.

${ }^{15}$ KAUFFMAN, 1987, passim; LUHMANN, 2007, p. 32.

${ }^{16}$ FOERSTER, 2002; LUHMANN, 2007, p. 44.

${ }^{17}$ MATURANA/VARELA, 2001a, passim; MATURANA/VARELA, 2001b, passim; LUHMANN, 2007: p. 44-45.

${ }^{18}$ LUHMANN, 2007, p. 62-63.

${ }^{19}$ LUHMANN, 2007, p. 49

${ }^{20}$ LUHMANN, 2007, p. 47.

${ }^{21}$ LUHMANN, 2007, p. 47.

${ }^{22}$ LUHMANN, 2007, p. 33.
} 
de sentido, a qual determina a ulterior evolução do ser humano"23, bem como porque "sentido é um mérito da comunicação sistêmica e não mérito da consciência nem uma representação de situações externas na consciência ${ }^{24}$.

Viver em sociedade é viver em comunicação, é viver, ao mesmo tempo, estabelecendo (fixando) e modificando (recriando) sentido. Com isso, o conceito de sentido é modelado por Luhmann de maneira que "o sentido se produz na trama das operações que sempre pressupõe sentido [...] sentido é um produto das operações que o usam, não uma qualidade do mundo devida a uma criação, fundação ou origem. Não há então idealidade separada do viver e do comunicar" ${ }^{25}$. Mais, a memória não nos leva ao verdadeiro, ela, sim, constrói estruturas de uso momentâneo, as quais conservam as condições mínimas para podermos selecionar o que constitui o sentido de algo e o que não o constitui. Por meio da memória, reduzimos as possibilidades de enlace entre os lados do sentido de algo.

Para explicar isso, Luhmann trata da teoria dos sistemas que formam sentido, como no sistema social e no psíquico, mas não no biológico. Luhmann distingue, pois, três tipos de sistema: sistemas vivos; sistemas psíquicos; e sistemas sociais. O primeiro contém limites materiais, de maneira que a relação entre as células e seu entorno se dá por espécies. Os limites dos outros dois sistemas são formas de dois lados. Eles realizam suas operações em forma de operação-de-observação, as quais só podem ocorrer no interior desses sistemas, pois só no interior é que dá a distinção autorreferência de heterorreferência ${ }^{26}$, ou seja, a distinção entre o que encontra referência sistêmica e, por isso, é valorado como interno ao sistema, o que não encontra referência, portanto, é valorado como ruído, como externo ao sistema. Cabe lembrar que tanto o interno quanto o externo integram o sistema. Acontece que a relação do sistema com o seu entorno é operacionalmente incalculável, mas não por causa do entorno e, sim, do próprio sistema. Em relação à arte, para citar um exemplo, Luhmann escreve:

A distinção entre validez e não validez da 'law of crossing', assim como o conhecimento de que a validez é condição da não validez interna da obra de arte, designam - em sentido estritamente teórico - o processo de diferenciação do sistema da arte dentro do mundo operacionalmente impenetrável. ${ }^{27}$

Assim é porque, segundo Luhmann:

A unidade dos acontecimentos comunicativos não podem ser derivadas objetiva, subjetiva, nem socialmente. Justamente por isso, a comunicação cria para si o médium do sentido no qual incessantemente se estabelece se a comunicação seguinte busca seu problema na informação, no ato de dá-la-a-conhecer (expressar) ou no entendê-la. ${ }^{28}$

O sistema - ao mesmo tempo em que contém uma memória (memory function) que o permite recorrer às operações passadas (decisões anteriores) - confronta-se com um futuro indeterminável para ele mesmo. Para resolver esse paradoxo do sentido, Luhmann recorre ao conceito re-entry, em que "a indicação e a distinção estão indissoluvelmente entrelaçadas: quando qualquer indicação é feita, qualquer marca, criase uma distinção automaticamente entre esses dois estados: o marcado e o não marcado" 29 . Nas palavras de Luhmann: "todas as formas de sentido têm um lado oposto que inclui o que, no momento de ser utilizada, se exclui" 30 , o que "exige a condensação seletiva e, ao mesmo tempo, a generalização, a qual corrobora que aquilo que se distingue do outro pode ser designado como o mesmo" 31 .

Sentido, portanto, é "uma forma de operação histórica que, só com a sua utilização é que se enlaça o surgimento contingente e a indetermi-

\footnotetext{
${ }^{23}$ LUHMANN, 1996, p. 23-24, 140-141; LUHMANN, 2007, p. 147.

${ }^{24}$ LUHMANN, 2005a, p. 87

${ }^{25}$ LUHMANN, 2007, p. 27.

${ }^{26}$ LUHMANN, 2007, p. 28.

${ }^{27}$ LUHMANN, 2005b, p. 69

${ }^{28}$ LUHMANN, 2007, p. 50.

${ }^{29}$ MARKS-TARLOW/ ROBERTSON/ COMBS, 2009.

${ }^{30}$ LUHMANN, 2007, p. 25

${ }^{31}$ LUHMANN, 2007, p. 30.
} 
nação de aplicações futuras" ${ }^{32}$, principalmente porque "as identidades de sentido (objetos empíricos, símbolos, signos, números, frases só podem ser produzidas recursivamente" ${ }^{33}$. Sendo, portanto, sentido "o meio no qual as formas se realizam como operações do sistema" ${ }^{34}$, autopoiesis é a aceitação de que toda explicação deve partir das operações específicas reproduzidas no sistema a ponto de constituir o sistema. Afinal, autopoiesis não é produção da forma do sistema, mas resultado da diferenciação sistema/entorno. Dessa diferenciação dá-se o paradoxo de que, ao se desacoplar do entorno, no sistema surgem espaços de liberdade internos, os quais permitem a produção de indeterminação interna no sistema. O sistema contém, portanto, unidade, estrutura e forma, ao mesmo tempo em que contém desordem, indeterminação e o outro lado da diferença (da forma). Numa frase: "o acomplamento estrutural tanto separa quanto vincula os sistemas" ${ }^{\prime 3}$.

Ao acrescer a teoria dos discursos constituintes de Dominique Maingueneau à teoria da sociedade de Luhmann, para desenvolver nossa teoria reflexiva da decisão jurídica, obtemos uma concepção de discurso que Luhmann não explora, bem como acrescemos à visão de sentido de Luhmann que "sentido é fronteira e subversão da fronteira, negociação entre pontos de estabilização da fala e forças que excedem toda localidade"36 e que "enunciar não é somente expressar ideias, é também tentar construir e legitimar o quadro de sua enunciação" ${ }^{37}$. Elementos importantes para observamos como é possível o STF incluir na expressão "entidade familiar" a união de pessoas do mesmo sexo. Numa frase, adicionar a teoria dos discursos constituintes à teoria da sociedade de Luhmann agrega à explicação da decisão jurídica a concepção dos elementos constituintes do discurso, incluindo a visão de que no espaço discursivo, o "Outro" não é um fragmento localizável, uma citação, nem uma entidade exterior, é o próprio discurso, pois, esse "Outro", é a parte de sentido que foi sacrificada para que o discurso pudesse constituir sua identidade. Disso decorre o caráter essencialmente dialógico de todo enunciado do discurso, a impossibilidade de dissociar a interação dos discursos do funcionamento intradiscursivo. Essa imbricação do "Mesmo" e do "Outro" retira à coerência semântica das formações discursivas qualquer caráter de "essência", caso em que sua inscrição na história seria assessória; não é dela que a forração discursiva tira o princípio de sua unidade, mas de um conflito regrado ${ }^{38}$.

Por fim, com Luiz Antônio Marcuschi, agregamos à nossa teoria a concepção de leitura como trabalho social. Marcuschi explora o sociointerativismo da cognição de Vygotsky ${ }^{39}$, do que escreve: "compreender é uma atividade colaborativa que se dá na interação entre autor-texto-leitor ou falante-texto-ouvinte" 40 ; "o sentido não está no leitor, nem no texto, nem no autor, mas se dá como um efeito das relações entre eles e das atividades desenvolvidas" $"$.

Luiz Antônio Marcuschi também escreve: "compreender bem um texto não é uma atividade natural nem uma herança genética; nem uma ação individual isolada do meio e da sociedade em que se vive. Compreender exige habilidade, interação e trabalho" "42. Ao desenvolver essa concepção, faz as seguintes afirmações: $1^{\text {a }}$ ) "nunca exercemos total controle sobre o que o entendimento que nosso enunciado possa vir a ter"; $2^{\circ}$ ) "compreender é também um exercício de convivência sociocultural"; $3^{\circ}$ ) "o leitor não é um sujeito consciente e dono do texto, ele se acha inserido na realidade social e tem que operar sobre conteúdos e contextos socioculturais" ${ }^{\prime 3}$.

\footnotetext{
${ }^{32}$ LUHMANN, 2007, p. 30.

${ }^{33}$ LUHMANN, 2007, p. 30.

${ }^{34}$ LUHMANN, 2007, p. 40.

${ }^{35}$ LUHMANN, 2005, p. 508-509.

${ }^{36}$ MAINGUENEAU, 2008, p. 26.

${ }^{37}$ MAINGUENEAU, 2005a, p.

${ }^{38}$ MAINGUENEAU, 2005b, p. 39.

${ }^{39}$ MARCUSCHI, 2007a, p. 52-75; MARCUSCHI, 2008, p. 228.

${ }^{40}$ MARCUSCHI, 2008, p. 231.

${ }^{41}$ MARCUSCHI, 2008, p. 242

${ }^{42}$ MARCUSCHI, 2008, p. 231

${ }^{43}$ MARCUSCHI, 2008, p. 231
} 
Essas afirmações nos permitem observar que, para Marcuschi, a compreensão é um trabalho social $^{44}$ por se dar sob a realização de atividade inferencial, a qual consiste num ato de inserção num conjunto de relações ${ }^{45}$. Assim, ao observarmos a decisão judicial aplicamos a concepção de inferência, de leitura e de literalidade, tal como trazida pela teoria da compreensão como trabalho social de Marcuschi.

É o que esperamos deixar claro com o presente artigo, ainda que a limitação espacial (de páginas) não nos permita detalhar mais nossa teoria nem absolutamente todos os termos empregados. Para tais detalhamentos sugerimos leitura de outros trabalhos nossos.

Aqui apresentamos parte de nossas pesquisas, iniciamos com a maneira como os participantes do caso trabalharam as técnicas e os métodos de interpretação.

\section{TÉCNICAS E MÉTODOS HERMENÊU- TICOS: NEM LACUNA NEM LITERALI- DADE NEM ANALOGIA}

Ao observar os corpora da pesquisa, iniciemos com o tema da literalidade. Que literalidade esteve presente durante o debate sobre qual "interpretação conforme a constituição" é a adequada na interpretação, compreensão e aplicação do art. 1.723 do Código Civil Brasileiro (Lei n. 10.406 , de 10 de janeiro de 2002)?

Essa pergunta é intrigante após constatar que no art. 1.723 do Código Civil Brasileiro (CCB) e no parágrafo terceiro do art. 226 do texto constitucional está escrito: "é reconhecida como entidade familiar a união estável entre o homem e a mulher". Como assim, interpretar o art. 1.723 do Código Civil Brasileiro (Lei n. 10.406, de 10 de janeiro de 2002) conforme a Constituição? Na íntegra:
Art. 1.723. É reconhecida como entidade familiar a união estável entre o homem e a mulher, configurada na convivência pública, contínua e duradoura e estabelecida com o objetivo de constituição de família (CCB).

Art. 226. A família, base da sociedade, tem especial proteção do Estado (CF).

$\$ 3^{\circ}$ - Para efeito da proteção do Estado, é reconhecida a união estável entre o homem e a mulher como entidade familiar, devendo a lei facilitar sua conversão em casamento.

O caso "evidencia" o quanto a decisão jurídica é contingente, não por isso imprevisível, porquanto expectativa não é garantia causal de evolução histórica, como se um futurismo garantidor, mas potência, como meio/forma de sentido $^{46}$. É o que se pode ver ao contextualizar historicamente a temática.

Num resumo, entidade familiar, como todos os demais institutos jurídicos, foi, é e segue em formação. Vejamos a história. Os direitos resultantes da união de pessoas do mesmo sexo entram no sistema jurídico brasileiro referentes aos direitos de propriedade, quando ações judiciais de direito à pensão, INSS, divisão dos bens entre na separação do casal tiveram lugar no STJ, seguindo-se questões sobre o direito de criar filhos, adotar etc., até assumir a forma jurídica de entidade familiar. Maria Berenice Dias, em artigo, afirma que união homoafetiva não é apenas dividir economias, envolve sentimentos. É que direitos patrimoniais já vinham sendo reconhecidos em casos de relação homossexual. Berenice Dias alerta sobre o ir e vir, no Judiciário, do reconhecimento de direitos a esta maneira de união humana, pois os mais de oitocentos processos que tramitaram no Judiciário vêm sendo julgados de diversas maneiras. A autora identifica decisões judiciais que reconheceram direito de sucessão, direito relativo à pensão (INSS), direito de adoção, direitos relativos à mudança

\footnotetext{
${ }^{44}$ MARCUSCHI, $2007^{\circ}$, p. 77 ; MARCUSCHI, 2008, p. 229.

${ }^{45}$ MARCUSCHI, 2007b, p. 88.

${ }^{46}$ Forma de sentido é expressão usada por Luhmann para explicar que "sociedade é um sistema que estabelece sentido" (LUHMANN, 2007, p. 32). O sentido, forma de dois lados que é, é ao mesmo tempo o MÉDIUM em que as comunicações se desenvolvem e FORMA fixada devido à distinção LUHMANN, 2007, p. 32). O sentido, forma de dois lados que é, é ao mesmo tempo o MÉDIUM em que as comunicações se desenvolvem e FORMA fixada devido à distinção realizada (LUHMANN, 2007, p. 37). O sentido é, portanto, a unidade da distinção (paradoxo do distinguir e assinalar) resultado do processamento seletivo entre o sentido atual e o possível. Isso só é possível na sociedade como sistema de comunicação (sociedade funcionalmente diferenciada), porque nela, através da semântica elaborada de reflexão, de autonomia, são constituídas formas (sistemas) de sentido com funções específicas, como o direito, a economia, a política, a arte, a religião, a educação, a ciência.
} 
de nome e sexo em certidões de nascimento ${ }^{47}$.

Aos 10 de fevereiro de 1998, no Recurso Especial n. 148897/MG, que tramitou na $4^{\text {a }}$ Turma do Superior Tribunal de Justiça, relator Ministro Ruy Rosado de Aguiar, foi reconhecida a união homoafetiva como sociedade de fato. Aos 17 de junho de 1999, o Desembargador Breno Moreira Mussi do Tribunal de Justiça do Rio Grande do Sul, relator do Agravo de Instrumento n. 599075496, julgado na 8 a Câmara Cível, decide que ações judiciais envolvendo união entre pessoas do mesmo sexo devem tramitar em Vara de Família. Assim, a "novidade" da decisão de 5 de maio de 2011, do STF, não foi assim tão nova.

Esse histórico não está ocupado com um demonstrar evolução histórica, como se a decisão de maio de 2011 tivesse sido causa daquela, mas ele serve para apresentar o quanto o direito da sociedade está contingencialmente em fazimento. É o que se depreende do paradoxo do sentido ${ }^{48}$ - o que muda permanece - e de que comunicar é promover uma distinção, portanto é selecionar e distinguir. Ao comunicar diferenciamos o que nos referimos e o que não iremos nos referir. Com a mesma lógica, da diferenciação, o sentido contém o sentido estabelecido (firmado, fixado, sentido-atual) e o sentido afastado (não estabelecido, negado temporalmente, sentido-possível). Essa diferenciação nos permite observar que os elementos constituintes do sentido se acoplam de maneira firme e frouxa ${ }^{49}$, ou seja, uma parte constituinte do sentido forma a memória do sentido e uma parte é esquecida, momentaneamente afastada da comunicação. Aplicando essas perspectivas, observamos, ao pesquisar decisões judiciais, a constante re-entrada do sentido-possível no sentido-atual, ora de maneira firme, ora de maneira frouxa. Observamos, assim, o direito como sistema que observa, produzindo e se reproduzindo. Noutras palavras, aportes da teoria de Luhmann viabilizam explicar como é possível o STF incluir na expressão "entidade familiar" a relação de pessoas do mesmo sexo. É o que passamos a apresentar.

No dia 4 de maio, tiveram a palavra dez amici curiae; no dia 5 de maio, os ministros do STF anunciaram seus votos e, ao final, tivemos prolatada a decisão.

Quanto à literalidade da expressão "entidade familiar", os representantes da CNBB e da AEB afirmaram a impossibilidade de haver outra interpretação que não negar a equiparação, pois o texto constitucional é claro: apenas "união estável entre o homem e a mulher" é legalmente "entidade familiar" (lembrar o parágrafo terceiro do art. 226, da Constituição Federal Brasileira, acima descrito). Acontece que literalidade não é consequência causal de leitura(s).

Os demais amici curiae, favoráveis à equiparação, pautaram suas alegações pelo argumento da lacuna no direito. A literalidade, neste caso, está na ausência de vedação expressa à união de pessoas do mesmo sexo ser entidade familiar. Assim, no texto constitucional, a expressão "entidade familiar" comporta a inclusão da relação homoafetiva, afinal o direito já reconhece outras formas de união familiar diversa da família entre homem e mulher como "entidade familiar". Como a completeza do ordenamento jurídico se dá por decisão judicial, afinal não só de legislação vive o direito, cabe ao Judiciário decidir se a relação entre pessoas do mesmo sexo é uma das espécies juridicamente admissíveis de "entidade familiar".

Esse debate hermenêutico, especificamente de se tratar de lacuna, foi desdobrado na decisão, ainda que, assistindo aos vídeos, ouvimos o Relator Ministro Ayres Brito afirmar que não se trata de lacuna, mas de o STF decidir qual deve ser a "interpretação conforme a Constituição", dos incisos II e V do art. 19 c/c o art. 33 do Estatuto dos Servidores Públicos Civis do Estado do Rio de Janeiro (Decreto-Lei n. 220/1975) e do Art. 1.723 do CCB. Ao deslocar do debate sobre lacuna para a questão da "interpretação conforme a Constituição" resta afastada a discussão do ativismo judicial, portanto de se tratar de política jurídica. O debate fica centrado como questão hermenêutica, é quando a literalidade se torna tema.

\footnotetext{
${ }^{47}$ DIAS, 2008, p. 298; DIAS, 2010; DIAS, 2011

${ }^{48}$ LUHMANN, 2007, p. 40.

${ }^{49}$ LUHMANN, 2007, p. 39.
} 
Os amici curiae favoráveis à equiparação recorrem aos princípios constitucionais da igualdade, liberdade e dignidade da pessoa humana, para argumentar que a literalidade está constituída por diversos textos, afirmam que a ideia de justiça presente na Constituição Federal brasileira está pautada pela inadmissibilidade de discriminação, portanto, é inconstitucional toda legislação preconceituosa, toda legislação que nega o reconhecimento da união entre pessoas do mesmo sexo como equiparada à entidade familiar. Assim, a "literalidade" do texto constitucional (art. 226, $\S 3^{\circ}$ ) está constituída pelo suporte advindo dos princípios constitucionais. Há uma "inconstitucionalidade na Constituição", como afirma Carmem Lúcia.

Aplicando nosso aporte teórico, afirmamos que não há que confundir literalidade com haver mais de uma interpretação possíve $l^{50}$, inclusive, "na produção de sentido através da comunicação, a recursividade se obtém sobretudo por palavras de linguagem, as quais - ainda que sejam as mesmas - podem ser utilizadas nas mais diversas situações" ${ }^{51}$.

Com Marcuschi, temos a ideia de que o sentido é um partilhamento de conhecimentos. Como detalharemos mais adiante. O conteúdo de uma expressão, de um instituto jurídico não está já estabelecido previamente no texto, no poder do julgador nem em qualquer outro lugar. Esse conteúdo é estabelecido constantemente, afinal, sentido é forma de dois lados: memória e mudança; história e renovação $0^{52}$. Assim, podemos compreender como é possível se afirmar que a ausência de um regime jurídico específico para a união entre pessoas do mesmo sexo não pode implicar exclusão, nos termos da legislação atual, dessa união como espécie de entidade familiar.

Em seu voto, a Ministra Carmem Lúcia afirma: "sistema que é, a Constituição haverá de ser interpretada como um conjunto harmônico de normas, no qual se põe uma finalidade voltada à concretização de valores nela adotados como princípios" (Item 5 do Voto).

Ainda, sobre literalidade, o Ministro Marco
Aurélio afirma:

Consoante Pietro Pierlingieri, a 'família não fundada no casamento é, portanto, ela mesma uma formação social potencialmente idônea ao desenvolvimento da personalidade dos seus componentes e, como tal, orientada pelo ordenamento a buscar a concretização desta função' ( $\mathrm{O}$ direito civil na legalidade constitucional, 2008, 989). Se o reconhecimento da entidade familiar depende apenas da opção livre e responsável de constituição de vida comum para promover a dignidade dos partícipes, regida pelo afeto existente entre eles, então não parece haver dúvida de que a Constituição Federal de 1988 permite seja a união homoafetiva admitida como tal. Essa é a leitura normativa que faço da Carta e dos valores por ela consagrados, em especial das cláusulas contidas nos artigos $1^{\circ}$, inciso III, $3^{\circ}$, incisos II e IV, e $5^{\circ}$, cabeça e inciso I (ver 10, do voto).

Observe a expressão "essa é a leitura normativa que faço da Carta e dos valores por ela consagrados [...]". A literalidade, portanto, não está dada ou estabelecida previamente, ela é constantemente construída.

No debate também há referência à analogia como recurso hermenêutico admitido para fundamentar a decisão, o reconhecimento da união homoafetiva como entidade familiar. Acontece que analogia é também negada como método hermenêutico para o caso. É o que ouvimos do Ministro Ayres Brito, relator do processo, ao afirmar que a maneira de conferir "interpretação conforme a Constituição" para decidir pela equiparação é porque a Constituição Federal contém dispositivos legais que impedem aplicação discriminatória. Com isso, o Ministro afirma que não se trata de analogia, mas sim que não é constitucional discriminação entre uniões heterossexuais e homossexuais.

Para uma compreensão de como foi possível essa decisão do STF, temos por literalidade não uma conclusão dedutiva causal pré-determinada no e pelo texto. A literalidade, aplicando a perspectiva teórica que estamos propondo, é construída no decorrer da formação discursiva. Com Luhmann, lembramos mais uma vez que sentido é forma de dois lados, ele é memória e mudan-

\footnotetext{
${ }^{50}$ POSSENTI, 2004, p. 232-234.

${ }^{51}$ LUHMANN, 2007, p. 30.

${ }^{52}$ LUHMANN, 2007, p. 43.
} 
ça. Com Luiz Marcuschi, temos a "literalidade como saliência”. De Giora, para quem o contexto influencia a compreensão, Marcuschi fala em produção de sentido segundo a saliência da literalidade. Giora equaciona o "modelo pragmático estandar", a "perspectiva do acesso direto" e a "hipótese da saliência gradual (HSG)" para afirmar que quanto mais familiar uma expressão, tanto mais rápido se dá a sua compreensão $0^{53}$. Estamos diante da concepção interacionista da linguagem, a qual Marcuschi considera adequada para se compreender o processo de produção de sentido, portanto, a língua como trabalho social. Afinal:

\begin{abstract}
No caso das teorias do paradigma da inferência temos uma crença generalizada na possibilidade da comunicação intersubjetiva e no partilhamento de conhecimentos como um dado. Acredita-se que a capacidade inferencial é mais ou menos natural e intuitiva. Seguramente, nem tudo é assim e mais do que isto, a compreensão, mesmo sendo em boa medida uma atividade inferencial em que os conhecimentos partilhados vão exercer uma boa dose de influência, seria ingênuo acreditar que isso se dá de maneira não problemática, pois o mal entendido é um fato. Um desafio no paradigma inferencial é explicar a suposição de expectativa de partilhamento de conhecimentos ${ }^{54}$.
\end{abstract}

Nessa perspectiva, não cabe confundir a inferência na perspectiva interacionista, com inferência como operação lógica. Uma maneira de evitar essa confusão é admitir que o sentido literal não ignora "o papel da interação na produção de sentido" ${ }^{55}$, portanto, o interacionismo aqui não é o interacionismo social (como o interacionismo simbólico com George Mead e Herbert Blumer, de cunho fenomenológico e psicossocial), mas uma concepção de "interação como processo de produção de sentidos pela relação entre seres humanos inter-objetivamente comunicantes" $" 56$. Aplicando essa concepção, podemos observar, do debate durante a decisão, o lugar atribuído ao sentimento, quando se afirma, por exemplo, que ao lado da tradicional família patriarcal, de base patrimonial e constituída, predominantemente, para os fins de procriação, outras formas de convivência familiar, fundadas no afeto, e nas quais se valoriza, de forma particular, a busca da felicidade, o bem-estar, o respeito e o desenvolvimento pessoal de seus integrantes.

Observada a inclusão de elementos na forma de sentido da entidade familiar, tais como o recurso à expressão dignidade humana, liberdade de escolha do como ser feliz, envolvendo a colmatação da lacuna por meio da técnica hermenêutica da analogia ou por interpretação extensiva, os debates sobre qual técnica hermenêutica aplicar foram esvaindo-se, principalmente quando se observa que o resultado decisório seria o mesmo (todos decidiram favorável à equiparação), ainda que cada Ministro tenha apresentado fundamentos diversos. Vejamos.

O relator, Ministro Ayres Brito, insiste, tomando a palavra durante o pronunciamento do voto do Ministro Gilmar Mendes, que:

[...] não há lacuna e portanto não há colmatação. Nós demos um tipo de interpretação superadora da literalidade e apontando que a própria constituição contém elementos interpretativos que habilitam esse julgamento do Supremo a concluir pela paridade de situações jurídicas, sem lacuna e portanto sem colmatação.

O Ministro Gilmar Mendes retoma a palavra para insistir que há omissão legislativa a ser suprida por decisão do STF. Já o Ministro Marco Aurélio fala em interpretação extensiva quando afirma que: "concordo que a constituição contém normas muito claras e direitos fundamentais que permitem a pretensão formulada. Se vamos aplicar por extensão ou por analogia ou de outra forma, o resultado é o mesmo a que vamos nos aproximar". Retoma novamente a palavra o Ministro Gilmar Mendes, continuando a questão de se a decisão é um caso de ato legislativo realizado pelo STF, afirmando:

A vida cotidiana do funcionamento parlamentar oculta o perigo de que maiorias se imponham desconsideradamente, emoções determinem o acontecimento, dinheiro

\footnotetext{
${ }^{3}$ MARCUSCHI, 2007a, p. 89.

${ }^{54}$ MARCUSCHI, 2008, p. 238.

${ }^{55}$ MARCUSCHI, 2007a, p. 94.

${ }^{56}$ MARCUSCHI, 2007a, p. 94.
} 
e relações de poder dominem e simplesmente sejam cometidas faltas graves. Um Tribunal Constitucional que se dirige contra tal, não se dirige contra o povo, senão em nome do povo contra seus representantes políticos. Ele não só faz valer negativamente que o processo político, segundo critérios jurídicos humanos e jurídicos fundamentais fracassou, mas também exige positivamente que os cidadãos aprovem os argumentos do Tribunal, se eles aceitarem o discurso jurídico constitucional racional. A representação argumentativa dá certo quando o Tribunal Constitucional é aceito como instância de reflexão do processo político. Isso é o caso quando os argumentos do Tribunal encontram eco na coletividade e nas instituições políticas conduzem a reflexões e discussões que resultam em convencimento examinados. Se um processo de reflexão entre coletividade, legislador e tribunal constitucional se estabiliza duradouramente, pode ser falado de uma institucionalização que deu certo dos direitos do homem num estado constitucional democrático. Direitos fundamentais e democracia estão reconciliados.

Observamos a preocupação de alguns ministros do STF em legitimar a decisão como decisão judicial e não política do direito (para lembrar Kelsen), os quais frisam que sua decisão não é um ato legislativo, mas um ato jurídico eivado de aceitabilidade social. Para observar essa questão, recorremos à ideia de fechamento operacional do sistema jurídico, nos moldes luhmannianos. Curioso como ainda há quem afirme que autonomia de funcionamento se confunde com isolamento. Bastava ler um parágrafo da obra de Luhmann para mudar essa afirmação, pois não faltaram tintas para Luhmann explicar que sua base teórica está na teoria da distinção de George Spencer Brown, para quem a forma tem dois lados, um lado positivo, afirmativo, inclusivo, e um lado negativo, distinguido, excluído. É que, ao comunicar, realizamos o paradoxo da distinção, pois assinalamos e distinguimos, ao mesmo tempo. Afirmar é decidir o incluído na comunicação, deixando de fora - excluindo sem eliminar, afinal sentido é uma forma de dois la$\operatorname{dos}^{57}$ - muito mais possibilidades que aquela que foi a comunicada. A comunicação é, pois, improvável, todavia nós, seres humanos, criamos meios (medium) para dar forma à comunicação, ou seja, para tornar a comunicação possível. Essas ideias aplicadas às falas durante a audiência no STF nos levam a considerar que o direito não é aplicação de legislação, nem uma questão de poder do julgador, mas um sistema de sentido, um sistema de comunicação no qual estão presentes a infinitude de possibilidades, todavia umas marcadas (lado inclusivo $=$ marked space) e outras não marcadas (unmarked space). Direito, assim considerado, é um sistema de comunicação da sociedade. Sistema é, nessa visão, produzido das comunicações sociais ${ }^{58}$. Todavia, não porque o sentido se opera dentro do sistema, ao operar o sentido ignora, desconhece, independe, é isolado do ambiente. Não. O sentido, forma de dois lados que é, contém o lado sistema (interno, inclusivo) e o lado entorno (externo, exclusão). Assim é porque o sistema vive acoplado ao seu ambiente de maneira que seu fechamento operacional estabelece os limites do sistema mesmo (autopoieticamente o sistema produz sentido por autorreferenciação).

Fique claro. Não há isolamento do sistema ao seu meio, ao seu ambiente, pelo contrário, há constante relacionamento, há acoplamento. Ser autopoiético é apenas admitir que se produzem estruturas e elementos no interior do sistema; ocorre que sendo forma de dois lados, também no interior do sistema se produzem espaços de liberdade internos ${ }^{59}$. Com isso, apenas chamamos atenção para o quanto um tribunal se ocupa com sua legitimidade, ou seja, com ser reconhecido socialmente, pois sabe que suas operações (decisões) não terão efeito de sentido se assim não for. Observamos que todas as falas se pautam por elementos do próprio mundo jurídico, do próprio direito com sistema de comunicação da sociedade. Assim não fosse, não seria pos-

\footnotetext{
${ }^{53}$ MARCUSCHI, 2007a, p. 89.

${ }^{54}$ MARCUSCHI, 2008, p. 238.

${ }^{55}$ MARCUSCHI, 2007a, p. 94.

${ }^{56}$ MARCUSCHI, 2007a, p. 94.

${ }^{57}$ LUHMANN, 2007, p. 28.

${ }^{58}$ LUHMANN, 2007, p. 39.

${ }^{59}$ LUHMANN, 2007, p. 45.
} 
sível compreender o que o outro enuncia, a fala de um não seria inteligível pelo outro. Ouvindo os enunciados durante a audiência observamos o quanto os outros debatem, discutem um e outro enunciado, o que implica ter havido comunicação, porquanto todos limitados ao fato de estarem num tribunal superior, argumentando, buscando ser ouvido, ser compreendido, comunicar-se. Não cabe a ilusão que comunicar é anuir porquanto há comunicação quando resulta acordo, concordância. Comunicação, na teoria reflexiva da sociedade somo sistemas que observam, é "operação elementar da sociedade, é um acontecimento atado a um instante de tempo, enquanto surge, se desvanece" ${ }^{\circ 0}$.

Assim, uma fala, um enunciado num tribunal não constitui por si só direito ou produção de direito, nem mesmo uma decisão por si mesma é já direito, assim fosse direito não seria sistema de comunicação sobre lítico/ilícito da sociedade, mas sim interação ou enunciado, nem sequer discurso seria. Se é sistema de comunicação, o direito, na medida em que se diferencia de seu entorno (diferencia-se tanto dos outros sistemas da sociedade como de seu ambiente) não se isola, afinal diferenciação é construção recursiva de um sistema, é aplicação da construção sistêmica ao resultado da própria diferenciação ${ }^{61}$. O sistema, portanto, vive integrado (acoplado) ao seu meio (entorno, ambiente), o que promove redução do grau de liberdade do próprio sistema. Com isso, observamos o quanto o sistema se adapta, aprende com o ambiente. Neste caso, a formação histórica do debate foi produzindo uma ambiência viável à inclusão da união entre pessoas do mesmo sexo na decisão do STF. Fosse essa decisão há cinco dez anos atrás, ela não teria tido o conteúdo que teve.

\section{O QUADRO CÊNICO: A INTERCOM- POSIÇÃO DO DISCURSO JURÍDICO}

Para lidar com o quanto cada participante se dedica a traçar cenas para legitimar seu discurso enunciado, recorremos à análise de discurso, da qual retiramos a ideia de que, por mais não jurídico que seja um argumento enunciado, discursivamente se pode identificar a pretensão em involucrar um argumento como integrante do discurso jurídico. Isso é constatado quando, por exemplo, o representante enviado pela igreja católica para falar na audiência do STF não foi um bispo ou um arcebispo, mas um advogado, portanto alguém com domínio do se comunicar nos moldes do discurso jurídico, do sistema jurídico. Todavia, qual a legitimidade do STF para tomar tal decisão? Justamente a legitimidade de organização central do direito da sociedade.

O tema da legitimidade do STF para tomar decisões como essa traz ao debate questões como o ativismo judicial, ou seja, o quanto o STF está ocupando função de legislador. O representante AEB afirmou que "esqueceram de falar o princípio mais importante da carta constitucional [...] 'todo poder emana do povo', art. $1^{\circ}$, parágrafo único" e, seguindo, com sete minutos de fala, questiona "por que Cabral e Dilma não fazem um plebiscito? Porque sabem que vai perder. O povo brasileiro não aceita, ele tem sua cultura enraizada".

O Ministro Ayres Brito relata que consultou todos os tribunais estaduais e assembleias estaduais, obtendo por resultado que a maioria declarou concordar com a equiparação entre essas uniões humanas. Sobre o tema, citamos o seguinte enunciado no voto do Ministro Ricardo Lewandowski:

O que se pretende, ao empregar-se o instrumento metodológico da integração, não é, à evidência, substituir a vontade do constituinte por outra arbitrariamente escolhida, mas apenas, tendo em conta a existência de um vácuo normativo, procurar reger uma realidade social superveniente a essa vontade, ainda que de forma provisória, ou seja, até que o Parlamento lhe dê o adequado tratamento legislativo (ver 12-13, do voto).

Para observar com foi possível a decisão do STF, verificamos a copresença de distintos discursos constituintes nas enunciações dos

\footnotetext{
${ }^{60}$ LUHMANN, 2007, p. 49.

${ }^{61}$ LUHMANN, 2007, p. 473.
} 
falantes, para isso aplicamos a ideia de cena da enunciação e de discurso constituinte com Maingueneau, inclusive porque:

\begin{abstract}
Maingueneau desenhou um quadro teórico que, a meu ver, oferece novos instrumentos para dar conta dos processos enunciativos [...] o que é mais original em Maingueneau, a meu ver, é a consideração de que os processos enunciativos não obedecem necessariamente à mesma ordem, conforme se trata, por exemplo, de ciência, de literatura, de política, de publicidade etc ${ }^{62}$.
\end{abstract}

E, ao final do texto, quando Possenti escreve: "Ele [Maingueneau] permite que fique claro que sua ordem (do texto) não decorre de uma possível liberdade dos sujeitos, mas também que ela é maior ou menor (que pode vir a se exigida!!!) segundo tipos de discurso"63.

Assim como Luhmann e Marcuschi, Maingueneau também não se pauta pela causalidade, mas pela gnosiologia e epistemologia da circularidade reflexividade, afinal, este autor também não se ocupa em buscar a essência ou a origem de um discurso. Pela via da circularidade reflexiva, a história, por exemplo, não se reduz à confecção de continuidades, ela é observada, também, como descontinuidades, como nos alerta Foucault:

[...] discurso não é uma forma ideal e intemporal que teria, além do mais, uma história [...] é, de parte a parte, histórico - fragmento de história, unidade e descontinuidade na própria história, que coloca o problema de seus próprios limites, de seus cortes, de suas transformações, dos modos específicos de sua temporalidade, e não seu surgimento abrupto em meio a cumplicidades do tempo ${ }^{64}$.

Com Maingueneau, os enunciados dos discursos constituintes são fechados em sua organização interna ao mesmo tempo em que são reinscritíveis em outros discursos (são capazes de se impor e remodelar para incluir no- vos enunciados $)^{65}$. Com Luhmann, a sociedade (sistema de comunicação) é possível por termos desenvolvido capacidade de produzir formas de sentido, formas estas que "têm um lado oposto que inclui o que, no momento em que são utilizadas, se exclui", afinal:

[...] o mundo é um potencial de surpresas ilimitado; é informação virtual que, não obstante, necessita de sistemas para gerar informação; melhor dizendo, para dar sentido de informação a certas irritações selecionadas. Por conseguinte, toda identidade deve ser entendida como resultado do processamento de informações ${ }^{66}$.

Com a teoria reflexiva, portanto, sociedade e discurso são rastros do contínuo e ao mesmo tempo do descontínuo do texto, do enunciado, do social, do discurso, pois o dito e o não dito integram o dito. Assim, ideias como discurso constituinte ${ }^{67}$ e meios de comunicação simbolicamente generalizados ${ }^{68}$ viabilizam reflexões e pesquisas diversas daquelas ocupadas com o descobrir uma origem, desvelar segredos ocultos, determinar como deveríamos ser, estabelecer normas de decisão tais como critérios para um médico decidir se um paciente é ou não é psicopata, para um juiz decidir se algo é lícito ou ilícito, para um leitor interpretar. Dispensados das amarras epistemológicas, não está o observador livre para observar como queira; os limites são institucionalizados pela própria condição de observar, como explica a ideia de paratopia, localidade paradoxal do autor (filósofo, escritor, sociólogo etc.), o qual não se pode pôr "nem no exterior nem no interior da sociedade", pois "sua enunciação se constitui na impossibilidade mesma de atribuir para si um verdadeiro 'lugar'" ${ }^{69}$. A paratopia é um pertencimento paradoxal ${ }^{70}$.

A própria definição dos corpora da pesquisa é suficiente para estabelecer limites gnoseológicos e epistemológicos. Documentos catalogados não

\footnotetext{
${ }^{62}$ POSSENTI, 2008, p. 203.

${ }^{63}$ POSSENTI, 2008, p. 203.

${ }^{64}$ FOUCAULT, 1986, p. 136

${ }^{65}$ MAINGUENEAU, 2008, p. 37.

${ }^{66}$ LUHMANN, 2007, p. 29.

${ }^{67}$ MAINGUENEAU, 2008, p. 37-54; MAINGUENEAU, 2010, p. 158.

${ }^{68}$ LUHMANN, 2007, p. 245-309.

${ }^{69}$ MAINGUENEAU, 2008, p. 45.

${ }^{70}$ MAINGUENEAU, 2008, p. 159.
} 
fornecem nem desvelam histórias (para lembrar mais uma vez Foucault), mas viabilizam análises, pesquisas, pois sem um corpus de pesquisa sequer, não há o que analisar. Se questionamos como foi possível, aos cinco dias do mês de maio do ano de dois mil e onze, o STF ter decidido que a união homoafetiva é, juridicamente, equiparada à entidade familiar, precisamos estabelecer os corpora à análise, estabelecer a cena da enunciação, afinal, texto são "rastros deixados por um discurso em que a fala é encenada" $"$.

Fosse direito exclusivamente legislação, toda mudança social seria necessariamente ilícito até alterada a legislação. Para uma explicação da ambivalência ordem/mudança no direito somamos a ideia de discurso constituinte, à teoria da sociedade como sistema comunicacional. Fosse direito pré-determinado por texto legislativo, jurisprudencial, doutrinário, como explicar a decisão do STF que equiparou a união homoafetiva com entidade familiar?

Para uma reflexão sobre essa questão, recorremos à ideia de discurso constituinte de Dominique Maingueneau, para quem "o sentido é fronteira e subversão da fronteira, negociação entre pontos de estabilização da fala e forças que excedem toda localidade" 72 e "enunciar não é somente expressar ideias, é também tentar construir e legitimar o quadro de sua enunciação" "73. Além disso:

[...] no espaço discursivo, o Outro não é nem um fragmento localizável, uma citação, nem uma entidade exterior; não é necessário que seja localizável por alguma ruptura visível da compacidade do discurso. Encontra-se na raiz de um Mesmo sempre já descentrado em relação a si próprio, que não é em momento algum passível de ser considerado sob afigura de uma plenitude autônoma. É o que faz sistematicamente falta a um discurso e lhe permite fechar-se em um todo. É aquela parte de sentido que foi necessário que o discurso sacrificasse para constituir sua identidade. Disso decorre o caráter essencialmente dialógico de todo enunciado do discurso, a impossibilidade de dissociar a interação dos discursos do funcionamento intradiscursivo. Essa imbricação do Mesmo e do Outro retira à coerência semântica das formações discursivas qualquer caráter de 'essência', caso em que sua inscrição na história seria assessória; não é dela que a forração discursiva tira o princípio de sua unidade, mas de um conflito re$\operatorname{grado}^{74}$.

Aqui, tem lugar a questão do quadro cênico. Ora, não analisamos pronunciamentos numa audiência do STF, analisamos discursos. Não por isso, arvoramo-nos a estabelecer um conceito de discurso. Assim como o termo direito, sociedade, estado, indivíduo, pessoa, discurso não é referido com uniformidade. Obviamente. Para não confundir discurso com enunciado, argumento ou texto, Maingueneau propõe como discurso o "artefato constituído para e por um procedimento de análise que terá a função de situar e configurar, em dado espaço-tempo, enunciados em arquivo"75. A complexidade do termo discurso nos leva à ideia de o discurso, simultaneamente, ser constituído por: a) supõe uma organização transfrástica (o discurso é uma organização situada para além da frase, porquanto vivenciam regras de uma organização, de uma comunidade discursiva); b) é orientado; c) é uma forma de ação; d) é interativo; e) é contextualizado; f) é assumido; g) é regido por regras, normas; h) é considerado no bojo de um interdiscurso ${ }^{76}$.

Não nos cabe aqui esclarecer cada uma dessas características do discurso, todavia, devido a elas, essa concepção de discurso está situada na perspectiva pragmática e, inclusive, diferenciado de texto e enunciado, porquanto textos são "unidades verbais pertencentes a um gênero de discurso" e enunciado, a diferença de enunciação, é uma "marca verbal de um acontecimento que é a enunciação" 77 .

Visualizamos, pois, discurso jurídico como uma espécie de discurso que contém regras, limites, organicidade (o discurso, como unidade transfrástica, está submetido às regras de

\footnotetext{
${ }^{71}$ MAINGUENEAU, 2005a, p. 85.

${ }^{72}$ MAINGUENEAU, 2008, p. 26.

${ }^{73}$ MAINGUENEAU, 2005a, p. 93

${ }^{74}$ MAINGUENEAU, 2005b, p. 39

${ }^{75}$ MAINGUENEAU, 2005a, p. 61

${ }^{76}$ MAINGUENEAU, 2005a, p. 52-56; MAINGUENEAU, 2005b, p. 21-25.

${ }^{77}$ MAINGUENEAU, 2005a, p. 56-57
} 
organização vigentes em um grupo social determinado), temporalidade (o discurso é orientado inclusive por se desenvolver no tempo), contextualidade (o sentido do discurso requer a contextualização do enunciado, da identificação de sujeitos como fontes de referências pessoais, temporais e espaciais, além da modalização), interatividade constitutiva (dialogismo, interdiscurso).

Com essa noção de discurso, questionamos: quando podemos considerar um texto, um enunciado, um discurso como jurídico? Para uma resposta recorremos à ideia de unidades tópicas territoriais $^{78}$. Assim, texto legislativo (Constituição Federal, Código Civil, Código de Processo Civil etc.), petição (documentos elaborados pelas partes, portanto decisões de advogados, promotores, procuradores, defensores públicos, no qual estão escritas informações sobre o caso e requerimento de decisão(ões) do magistrado), decisão de magistrados (despacho, sentença, acórdão, súmulas, voto em decisões colegiadas) configuram unidades tópicas territoriais do discurso jurídico, pois integram o tipo de discurso relacionado ao setor de atividade da sociedade chamado direito; assim consideramos porque o tipo de discurso jurídico comporta os gêneros de discurso legislação, petição, despacho, sentença, voto, acórdão.

Ocorre que outros dados integram o corpus da pesquisa e, então, cabe pensar se é o caso de lidarmos com unidades não tópicas como formações discursivas ${ }^{79}$, pois discursos provenientes de igrejas, para serem considerados discursos jurídicos, é preciso aportar sua transversalidade ao promover uma análise de discurso. É o que temos com a inclusão do discurso religioso como jurídico, como ocorreu nos casos da legalização de pesquisa com célula tronco, aborto anacefálico, união homoafetiva, transexualidade. A questão é: quando o advogado da CNBB fala, sua fala já é discurso jurídico em si? Essa questão pode soar como devaneios acadêmicos, todavia sua importância está na concepção do direito como produto de comunicação da sociedade, portanto não como interpretação de textos legislativos, nem como poder do decididor. Entender que advocacia é organização do sistema jurídico, assim como são os tribunais implica admitir que não só juiz, desembargador ou ministro integram comunicação jurídica. Mais, implica verificar o quanto os amici curiae representam sociedade ou falas juridicizadas da sociedade. As implicações para uma compreensão da decisão dessa questão são diversas, uma delas é justamente as implicações da ambiência STF nos discursos dos falantes.

Seguimos essa questão explorando a ideia de cenas de enunciação. Para observar os discursos, portanto como foi possível a decisão do STF, é necessário considerar a cenografia. No quadro cênico, ou seja, na cena englobante [a que corresponde ao tipo de discurso jurídico e ao seu estatuto pragmático, viabiliza identificar os lugares (estatutos) dos parceiros e o quadro espaciotemporal, é ela que nos permite considerar os enunciados como integrantes do discurso de tipo jurídico] e na cena genérica [da qual identificamos o papel dos parceiros, as circunstâncias espacial e temporal, o suporte material e a finalidade das falas de cada parceiro na audiência do STF] "definem o espaço estável no interior do qual o enunciado adquire sentido" ${ }^{" 80}$. Ocorre que este quadro cênico não é suficiente, pois as falas dos amici curiae $^{81}$, durante a audiência do STF, são legitimadas como discurso jurídico se considerarmos a cenografia. É que, devido ao processo de enlaçamento paradoxal - no qual "a enunciação, ao se desenvolver, esforça-se por instituir progressivamente seu próprio discurso de fala" 82 - podemos observar que um enunciado emitido por um representante da igreja, nas dependências do STF, portanto, num processo

\footnotetext{
${ }^{78}$ MAINGUENEAU, 2008, p. 16-17.

${ }^{79}$ MAINGUENEAU, 2008, p. 18-23.

${ }^{80}$ MAINGUENEAU, 2008, p. 116; MAINGENEAU, 2010, p. 188

${ }^{81}$ Conectas Direitos Humanos; Instituto Brasileiro de Direito de Família - IBDFAM; Grupo Arco-Íris de Conscientização Homossexual; Associação Brasileira de Gays, Lésbicas, Bissexuais, Travestis e Transexuais - ABGLT; Grupo de Estudos em Direito Internacional da Universidade Federal de Minas Gerais - GEDI-UFMG e Centro de Referência de Gays, Lésbicas, Bissexuais, Travestis, Transexuais e Transgêneros do Estado de Minas Gerais - Centro de Referência GLBTTT; ANIS - Instituto de Bioética, Direitos Humanos e Gênero; Associação de Incentivo à Educação e Saúde de São Paulo; Conferência Nacional dos Bispos do Brasil - CNBB e a Associação Eduardo Banks.

${ }^{82}$ MAINGUENEAU, 2008, p. 118.
} 


\section{PESQUISAS SOCIOJURÍDICAS}

judicial, configura um discurso jurídico por sua cena ser a audiência judicial realizada no STF.

Com isso, as falas dos amici curiae, por exemplo, dos representantes da igreja, são discursos jurídicos e não discursos religiosos. Assim é porque os discursos que originalmente são religiosos, políticos, reivindicatórios são transformados em jurídicos na medida de sua enunciação. É que:

[...] cenografia é, ao mesmo tempo, origem e produto do discurso; ela legitima um enunciado que, retroativamente, deve legitimá-la e estabelecer que essa cenografia de onde se origina a palavra é precisamente a cenografia requerida para contar uma história, para denunciar uma injustiça etc. ${ }^{83}$

O Ministro Luiz Fux, por exemplo, defende que julgar não é exclusivamente razão, mas também sentimento. Relata sua história como juiz de carreira para se referir à experiência de magistrado como responsável por decidir. Centra seu argumento no sentimento, no amor. Afirma que "justiça está em buscar justiça, não numa definição que se pode ter antecipadamente". Se ser homossexual não é crime, porque não constitui entidade familiar? "[...] por força de duas questões que são abominadas por nossa constituição: a intolerância e o preconceito". Cita o preâmbulo da Constituição Federal e, em seguida, o caput de seu art. $5^{\circ}$ e passa a citar legislações internacionais. O que é uma família no Brasil? '[...] família só tem propriedade quando nela há respeito pela dignidade humana. Se é assim, a união homoafetiva enquadra-se no conceito de família. A pretensão é conferir juridicidade à união homoafetiva, equiparando-a à entidade familiar". Não se justifica não admitir essa equiparação, pois inúmeros princípios constitucionais conspiram em favor dessa equiparação. Ex. isonomia, liberdade, dignidade da pessoa humana, proteção do Estado à pessoa etc. Fala em tecido normativo do texto constitucional. Afirma que "o ser humano se encontra como centro de gravidade de todo o ordenamento jurídico". Alega que se o legislador não faz sua função, cabe ao STF fazer, pois ele órgão do governo e como tal deve buscar aplicar o direito considerando a igualdade, o princípio que o governo garanta a todos viverem com dignidade. Então cita Ronald Dworkin, depois Hannah Arendt ao tratar da dignidade humana como valor fundamental à humanidade, à implementação de uma política que garanta uma vida com igualdade, liberdade e dignidade. Volta a citar autores do direito para firmar a dignidade humana. Por fim, recorre à máxima jurídica “onde está a sociedade, está o direito" para afirmar que se a sociedade evolui, o direito deve evoluir. Considera que este é um momento de ousadia judicial e, na continuidade, que, "se o legislador não quis fazer tal ousadia, cabe ao Tribunal fazê-la. Este é um momento da travessia, cabe ao STF fazê-la”. Cita, então, Fernando Pessoa. No fim, declara acompanhar o relator votando favorável à equiparação.

Nossas observações sobre esse voto do Ministro Luiz Fux é que ele está organizado desde as regras constitutivas do discurso jurídico, como ensina Maingueneau, porquanto estão presentes as regras do "mundo do direito", da comunidade discursiva jurídica. Como ministro, Fux tem poder de voto, sua fala não tem os mesmos moldes que as falas daqueles que não são ministros. Seu enunciado é constitutivo do discurso jurídico porquanto orientado por identificar normas jurídicas (legislativas ou não) favoráveis à equiparação; como forma de ação, o voto defende uma ideia de decisão justa; seu voto é eminentemente interativo, inclusive dialoga com os demais ministros e com peças processuais das partes, está contextualizado, dadas as circunstâncias ambientais (sala do STF, uso de toga, tom de voz etc.), o momento histórico social (o debate não é novo no mundo jurídico), é um discurso assumido (é um voto de um ministro do STF, tem elementos à formação do discurso jurídico); quanto interdiscurso, há citações explícitas de outros autores bem como aforismos como referência à sua história até o STF, seus sentimentos pessoais, apelos.

Todas essas observações têm lugar devido ao objetivo de explicar "como foi possível" o STF ter tomado a decisão jurídica que tomou no dia

${ }^{83}$ MAINGUENEAU, 2008, p. 118. 
cinco do mês de maio de 2011. Numa frase, isso foi possível porque direito é um sistema de comunicação da sociedade, portanto contingente, duplamente contingente porquanto limitado por seu entorno ao mesmo tempo em que limitado por seu interior.

Seguindo a análise, visando agora não mais compreender cada voto, mas a decisão do STF, descreveremos uma sequência de votos para só ao final lançar nossas observações.

A Ministra Ellen Gracie aponta que o tema é debater a "interpretação legitimadora" do art. 1.723, do Código Civil, de maneira a ser interpretado "conforme a constituição" e a incidir também sobre a união entre pessoas do mesmo sexo. Faz referências às peças dos autos. Cita a dignidade da pessoa humana como núcleo central da Constituição Federal. Se a união homoafetiva é estável, por que não é entidade familiar? Afirma que contra todas as formas de covardia e violência aplicadas contra as minorias, como preconceitos, é amplamente repudiado pelo ordenamento jurídico. Cita Guimarães Rosa para dizer que "a vida não é entendível", assim, afirma que "o direito existe para a vida, e não a vida para o direito". O que temos aqui é um debate sobre qual a melhor interpretação ao Código Civil, o qual repete o art. 226 da Carta Magna. O artigo 1.723 do Código Civil, mesmo contendo o mesmo texto do art. 226 da Constituição, deve ser interpretado afastando-se o preconceito. Como a interpretação do texto constitucional não comporta uma interpretação preconceituosa, pois sobre ele incidem os princípios constitucionais da liberdade, da dignidade humana, o Código Civil também não deve ser interpretado preconceituosamente.

Durante o voto, toma a palavra o Ministro Gilmar Mendes, e a Ministra Ellen Gracie lhe concede a palavra. O Ministro Gilmar Mendes afirma que "talvez o único argumento que pode quando se invoca a possibilidade de se ter a união entre pessoa do mesmo sexo, invoca-se o dispositivo do código civil como óbice", "Minha primeira pré-compreensão é que o texto não é excludente, não só com base no texto ou mesmo na constituição, mas no ordenamento jurídico [...]". Aqui observamos que nenhum método de interpretação é capaz de explicar tal decisão, muito menos a teoria da argumentação, por isso sugerimos uma teoria reflexiva, pois uma teoria reflexiva é capaz de explicar a produção do direito, a decisão jurídica em sua empiricidade. $\mathrm{O}$ que implica nos afastarmos da pretensão de ensinar juiz a decidir, como é frequente entre doutrinadores jurídicos.

Retoma a palavra a Ministra Ellen Gracie e afirma que a largueza da interpretação não está na literalidade. $O$ artigo não é literal porque, ao final, na segunda parte, a Constituição viabiliza a ampliação, por intepretação, do sentido de entidade familiar. A Constituição, afirma a ministra, não pode defender a intolerância, seus princípios maiores fazem com que a sirva para concretizar valores. É papel da hermenêutica constitucional a compreensão histórica, com a visão total de sua época: hermenêutica das palavras (gramaticalidade), do espírito (historicidade, contextualidade), do sentido (a constitucional) (cita José Afonso da Silva). A intepretação não pode se dar pela intolerabilidade da liberdade de escolha pela felicidade. A referência expressa a uma mulher não implica inferiorizar cada um de nós, excluir outras alternativas. Por fim, julga conforme o relator. Observamos aqui nitidamente a construção de sentido do direito. Construção esta que contém a aplicação da memória do sentido de entidade familiar, bem como dos tantos debates e ações judiciais já realizados, ao mesmo tempo em que há mudança desse sentido historicamente construído de entidade familiar.

O Ministro Ricardo Lewandowski argumenta que se tende a vincular família a casamento, aqui, cita as Constituições brasileiras anteriores. $\mathrm{Na}$ Constituição de 1988, identifica três tipos de famílias: união entre homem e mulher (casamento civil), união estável (de fato, concubinato) e a monoparental. União homoafetiva é entidade familiar aplicando o método sistemático, é um quarto tipo de entidade familiar, inclusive porque ela não é proibida pelo ordenamento. Cita Canotilho (38min.). Na ordem constitucional em vigor, família é a base da sociedade e merece proteção do Estado. O importante é proteger todas as formas de família social e não estabelecer como cada um deve constituir sua família. A falta 
de norma específica, não implica negar direitos às formas como as pessoas buscam ser felizes. No senso de 2010, o IBGE identificou $60 \mathrm{mil}$ casais homossexuais declarados no país. A relação duradoura é apta a ser aplicado o contido no art. 226, pois a textualidade "homem e mulher" é meramente exemplificativa, não taxativa. Assim, refere-se ao instrumento metodológico da integração, o que implica não se tratar de uma substituição do legislador, mas de suprir lacuna da legislação, ainda que de forma provisória. Esclarece, ainda, que não quer reconhecer uma união estável homoafetiva, por interpretação extensiva do art. 226, da Constituição Federal, mas uma união estável homoafetiva estável, dado o processo de integração analógica. Desvela-se outra espécie de entidade familiar. Reconhecida a união homoafetiva com entidade familiar, nos aspectos em que são assemelhados, através do emprego da analogia no âmbito jurídico. Vota em favor da aplicabilidade, por analogia, às uniões homoafetivas de todas as normas aplicáveis à união heteroafetivas. Mais uma vez, observamos a constante produção do sentido do direito inclusive explorando informações típicas do direito, como textos legais e jurisprudência, ao mesmo tempo em que explora informações não jurídicas.

O Ministro Joaquim Barbosa traz ao debate que se trata de interpretar considerando os preceitos que decorrem do núcleo estruturante da dignidade humana. Para isso recorre ao descompasso entre o mundo dos fatos e o universo do direito, pois o direito não foi capaz de acompanhar as mudanças sociais, papel da Corte Constitucional (Cortes Supremas). Com isso, defende que cabe a elas fazer a ponte entre o direito e a sociedade. As relações homossexuais não diferem em nada das heterossexuais, o que varia é como a sociedade trata dessas relações. Recorre à analogia e declara que comunga com o voto do relator, principalmente por a Constituição vedar a discriminação e mitigar pelo peso das desigualdades baseadas no preconceito. $\mathrm{O}$ art. $3^{\circ}$ da atual Carta de República é promover o bem de todos sem preconceitos, formas de discriminação. Vota com o relator.

Nossas observações sobre cada voto, cada fala, cada informação (enunciado) apresentados pelos participantes da audiência no STF nos levam a afirmar o quanto tem lugar uma teoria reflexiva da decisão judicial.

\section{OBSERVAÇÕES DOS DISCURSOS CON- STITUINTES NA FORMAÇÃO DISCUR- SIVA DO DIREITO DA SOCIEDADE}

Ao aplicar as contribuições da teoria reflexiva da sociedade como sistema de sentido para uma compreensão da decisão jurídica. Na literatura jurídica não faltam autores - Hans Kelsen e Herbert Hart, por exemplo - reconhecendo a impossibilidade de a legislação prever todas as formas e possibilidades de casos socialmente possíveis.

A "descoberta" da ambiguidade e da vagueza, por juristas, foi suficiente para limitar o debate jurídico à ideia de que, sendo o direito texto, a decisão jurídica é discricionária (Hans Kelsen, normativismo, e Herbert Hart, realismo analítico) ou é arbitrária, uma questão de poder (persuasão - retóricos). Essa dicotomia não viabiliza explicar a decisão jurídica, pois ela é arbitrária e discricionária, ao mesmo tempo. Para uma compreensão dessa afirmação, reproduzimos os arts. 126 e 131 do Código de Processo Civil (CPC):

Art. 126. O juiz não se exime de sentenciar ou despachar alegando lacuna ou obscuridade da lei. No julgamento da lide caber-lhe-á aplicar as normas legais; não as havendo, recorrerá à analogia, aos costumes e aos princípios gerais de direito. (Redação dada pela Lei $n^{\circ} 5.925$, de $1^{\circ} .10 .1973$ )

Art. 131. O juiz apreciará livremente a prova, atendendo aos fatos e circunstâncias constantes dos autos, ainda que não alegados pelas partes; mas deverá indicar, na sentença, os motivos que lhe formaram o convencimento. (Redação dada pela Lei $\mathrm{n}^{\circ} 5.925$, de $\left.1^{\circ} .10 .1973\right)$

Do artigo 126 destacamos a obrigatoriedade de decidir, o que implica ao Judiciário a função de estabelecer qual das partes de um processo judicial é a que detém determinado direito (jurisdictio), bem como a ideia de a decisão do juiz estar limitada à aplicação das normas legais. Do artigo 131 destacamos a ideia de livre apreciação 
da prova. Ambos os artigos trazem o paradoxo da liberdade limitada do julgador, ambivalência presente na liberdade de leitura, da interpretação, o que lembra a ideia de paratopia, pois o decididor, ao tomar a decisão, enuncia um direito e, essa enunciação está localizada no mundo jurídico, no discurso jurídico, logo não há que se falar em plena liberdade de decisão, mas em "cenas de enunciação", para usar uma expressão da análise de discurso de Maingueneau.

Recorrendo à análise de discurso, evitamos reduzir o debate a críticas (elogios, censuras e/ ou condenações) à decisão tomada, a exemplo de se afirmar que o julgador não sabe ler a legislação, como se decisão correta fosse exclusivamente aquela "ajustada" à correta interpretação, compreensão e aplicação da legislação ao caso. Observamos que várias técnicas hermenêuticas tiveram lugar no debate, inclusive para nortear o quanto os ministros se veem legislando e não tomando uma decisão judicial.

Em nossa perspectiva, aplicando ideias da teoria reflexiva do direito como sistema social de comunicação, sugerimos que para uma compreensão da decisão jurídica é impensável se se insiste na lógica causal. Certo é que a teoria reflexiva não é por si suficiente, pensássemos assim, cairíamos na tentação de imaginar haver uma única teoria da decisão jurídica; pelo contrário, há diversas teorias da decisão jurídica, apenas umas levam a umas reflexões e outras a outras. A amplitude da observação é uma questão do observador, não da teoria em si, do objeto em si.

Questionar, portanto, como foi possível o STF decidir pela inclusão da união homoafetiva no sentido de entidade familiar, levou-nos a observar, simultaneamente, as regras discursivas da organização jurídica (especificamente do Judiciário, especificamente, da audiência no Supremo Tribunal Federal, como produtor do discurso jurídico da sociedade), a interatividade constitutiva do direito (interdiscursividade), a produção de sentido do direito e o desenvolvimento do discurso no tempo (o discurso é orientado).

Adicionados elementos da análise de discurso à teoria da sociedade de Luhmann, pudemos observar que a constituição do direito da sociedade (portanto do discurso jurídico) é possível uma vez considerando a interioridade e a exterioridade, portanto os limites estabelecidos pelo próprio direito da sociedade ao mesmo tempo os limites de seu entorno, como observamos a presença de referências típicas do discurso jurídico (cenas de sua enunciação, a exemplo, enquadrarse em legislações, jurisprudências, doutrinas) ao mesmo tempo em que observamos a presença de referências ao entorno (ciência, política, economia, religião, amor).

Ao observar o quadro cênico, vimos o quanto não é suficiente para delimitar os argumentos (enunciados) referências às fontes formais do direito, o que nos leva a afirmar que a produção de sentido do direito da sociedade envolve interpretação de textos legislativos bem como inclusão das mais variadas fontes de informação, ou seja, a presença de informações de outros sistemas sociais na formação do sistema do direito da sociedade, ou a presença de outros discursos constituintes no discurso jurídico.

Ficam aqui nossas observações sobre dados da decisão do STF que firmou, juridicamente, a equiparação da união homoafetiva como entidade familiar. Decisão esta que foi possível porque o direito está em constante produção e reprodução de sentido. Se é assim, para explicar a decisão jurídica propormos uma teoria reflexiva, não um modelo teórico ou uma teoria definitiva, mas uma teoria também em constante construção. Fica, portanto, a proposta de a teoria reflexiva do direito como sistema social de comunicação ser uma alternativa às observações de como é possível a decisão judicial ser tal como é.

\section{REFERÊNCIAS}

DIAS, Maria Berenice. Família homoafetiva. De Jure - Revista Jurídica do Ministério Público de Minas Gerais. Belo Horizonte, MPMG, n.10, p. 292-314, jan./jul. 2008.

União homoafetiva não é apenas dividir economias. 2010. Disponível em: <http://www. conjur.com.br/2010-dez-24/stj-retrocedeconsiderar-uniao-homoafetiva-sociedade-fato $>$. Acesso em: 30 dez. 2010. 
As uniões homoafetivas no STJ. 2011. Disponível em: <http://www.mariaberenice.com. br/uploads/as_uni\%F5es_homoafetivas_no_stj. pdf $>$. Acesso em: 3 jul. 2014.

FOERSTER, Heinz von. Understanding, Understanding. Essays on cybernetics and cognition. New York/Berlin/Heidelberg: Springer, 2002.

FOUCAULT, Michel. Arqueologia do saber. Rio de Janeiro: Forense Universitária [1969], 1986.

LUHMANN, Niklas. La ciencia de la sociedad. México: Universidad IberoAmericana, 1996.

Sistemas sociales. Barcelona: Anthropos/

México: Universidad IberoAmericana/Santafé de Bogotá: PUC Javeriana, 1998.

El derecho de la sociedad. México: Universidad IberoAmericana/Herder, 2005.

La sociedad de la sociedad. México: Universidad IberoAmericana/Herder, 2007.

MAINGUENEAU, Dominique. Análise de textos de comunicação. São Paulo: Cortez, 2005a.

. Gênese dos discursos. Curitiba: Criar, 2005b.

Cenas da enunciação. São Paulo: Parábola, 2008.

Doze conceitos em análise de discurso. São Paulo: Parábola, 2010.

MARCUSCHI, Luiz Antônio. Fenômenos da linguagem. Reflexões semânticas e discursivas. Rio de Janeiro: Lucerna, 2007a.

Cognição, linguagem e práticas interacionais. Rio de Janeiro: Lucerna, 2007b.

Produção textual, análise de gêneros e compreensão. São Paulo: Parábola, 2008.
STAMFORD DA SILVA, Artur. Gödelização da racionalidade e o limite da decisão jurídica: desparadoxizando a dicotomias da hermenêutica desde a teoria dos sistemas de sentido com Niklas Luhmann. Revista Acadêmica (Faculdade de Direito do Recife). Recife, Nossa Livraria, n. LXXXI, p. 113-137, 2009.

. Decisão jurídica e mudança social. Para uma Sociologia da Decisão Jurídica. Revista Confluências. Rio de Janeiro, PPGSD, n. 11, p. 121-150, 2010.

Decisión judicial y cambios sociales en la óptica de la teoría de sistemas de sentido social. In: CADENAS, Hugo; MARCAREÑO, Aldo; USQUIZA, Anahí (Ed.). Niklas Luhmannn y el legado universalista de su teoría. Santiago de Chile: RIL. 2012. p. 267-316.

Teoria reflexiva da decisão jurídica: observações a partir da teoria dos sistemas que observam. In: SCHWARTZ, Germano (Org.). Juridicização das esferas sociais e fragmentação do direito na sociedade contemporânea. Porto Alegre: Livraria do Advogado, 2012. p. 29-58.

POSSENTI, Sírio. Sobre o sentido da expressão "sentido literal". Os limites do discurso. Curitiba: Criar Edições, 2004. p. 227-234.

Um dispositivo teórico-metodológico. Contribuições de Dominique Maingueneau para a análise do discurso no Brasil. São Carlos-SP: Pedro e João, 2008. p. 201-212.

\section{Recebido em: 15/02/2014}

